\title{
Interleukin-1 Generates Transmembrane Signals from Phospholipids through Novel Pathways in Cultured Rat Mesangial Cells
}

\author{
Mark Kester, Michael S. Simonson, Paolo Mené, and John R. Sedor \\ Department of Medicine, School of Medicine, Case Western Reserve University, and Division of Nephrology, \\ University Hospitals of Cleveland, Cleveland, Ohio 44106
}

\begin{abstract}
Although IL-1 stimulates cellular responses in both lymphoid and nonlymphoid cells, the second messengers by which IL-1 activates cells are unknown. Recombinant IL-1 $\alpha$ (rIL-1) is a comitogen for glomerular mesangial cells. Using this model we explored potential transmembrane signals by which IL-1 stimulates cellular responses. Certain mitogens hydrolyze inositol phospholipids by phospholipase $\mathbf{C}$ to generate 1,2-diacylglycerol, a cofactor for protein kinase $C$, and inositol $(1,4,5)$-trisphosphate, which mobilizes intracellular calcium. rIL-1 induced a peak increase in [ $\left.{ }^{3} \mathrm{H}\right] 1,2$-diacylglycerol formation at 1 min. Production of 1,2-diacylglycerol often parallels the generation of phosphatidic acid; however, rIL-1 stimulated [ ${ }^{32}$ P]phosphatidate formation only after $60 \mathrm{~min}$. rIL-1 did not change the inositol phosphate or cytosolic free calcium concentrations, demonstrating that rIL-1 does not activate an inositol phospholipid-specific phospholipase C. $\left[{ }^{3} \mathrm{H}\right]$ Phosphorylethanolamine, but not $\left[{ }^{3} \mathrm{H}\right]$ phosphorylserine or $\left[{ }^{3} \mathrm{H}\right]$ phosphorylcholine, was maximally elevated at $1 \mathrm{~min}$ in mesangial cells incubated with rIL-1. Radioactivity incorporated into phosphatidylethanolamine but not phosphatidylcholine was also decreased in IL-1-stimulated mesangial cells compared with control at $1 \mathrm{~min}$. These data suggest that rIL-1 activates a phospholipase $\mathrm{C}$ predominantly linked to phosphatidylethanolamine. In contrast to other mitogens, rIL-1 did not alter intracellular pH. Both 12-0-tetradecanoyl-phorbol-13-acetate, a homologue of 1,2-diacylglycerol, and phosphatidate but not phosphatidylcholine in the presence of $0.5 \%$ fetal bovine serum stimulated mesangial cell proliferation. rIL-1-induced cellular activation may be mediated, at least in part, by phospholipidderived second messengers generated through novel pathways.
\end{abstract}

\section{Introduction}

IL-1 represents a family of proteins, encoded by at least two distinct genes, that play a seminal role in systemic and local

This work was presented at the annual meeting of the American Society of Nephrology, Washington, DC, December 1987, and has been published in abstract form.

Address correspondence to Dr. John R. Sedor, Division of Nephrology, Department of Medicine, 2074 Abington Rd., Cleveland, OH 44106.

Received for publication 27 July 1988 and in revised form 16 September 1988 .

J. Clin. Invest.

(c) The American Society for Clinical Investigation, Inc.

$0021-9738 / 89 / 02 / 0718 / 06 \$ 2.00$

Volume 83, February 1989, 718-723 inflammatory responses (1). When incubated with IL-1, primary cells as well as cultured cell lines undergo a coordinated response that culminates in the expression of new structural determinants and functional characteristics (1). Little information is available, however, on the transmembrane messengers mediating IL-1-induced cellular activation. Our objective in this study was to explore the phospholipid-derived and ionic signals that may mediate the effects of IL-1 on cultured rat glomerular mesangial cells.

The mesangial cell occupies a central anatomical position within the glomerulus. It is a specialized pericyte that not only regulates glomerular filtration but also synthesizes, and responds to, a number of cytokines (2). Mesangial cells in culture contain IL-1 mRNA transcripts and release a protein that closely resembles IL-1 $(3,4)$. Both macrophage- and mesangial cell-derived IL-1 stimulate mesangial cells to proliferate and generate $\mathrm{PGE}_{2}$ and collagen (4). IL-1 also enhances mesangial cell secretion of a glomerular basement membrane-degrading neutral protease (4). IL-1 gene expression is increased in kidneys of animals with experimental nephritis (3), and considerable evidence has demonstrated that IL-1 acts locally to enhance tissue injury (1). Intraglomerular release of IL-1, therefore, may contribute to the structural and functional changes characteristic of glomerular immune injury.

\section{Methods}

Cell culture and DNA synthesis. Mesangial cells were grown from collagenase-digested glomeruli as previously described (3) and represent a uniform population of cells that is not contaminated by macrophages, endothelial cells, fibroblasts, or epithelial cells using morphological, immunohistochemical, and biochemical criteria (3). Cells were used in the third to sixth passage. To assess DNA synthesis, near confluent mesangial cells were held for $96 \mathrm{~h}$ in DME and Hamm's nutrient $\mathrm{F} 12$ medium (DME/F12, 1:1) containing 0.5\% fetal bovine serum (FBS). ${ }^{1}$ Cells remain viable but do not proliferate under these conditions. Cells were then incubated for $48 \mathrm{~h}$ with the indicated agents and $\left[{ }^{3} \mathrm{H}\right]$ thymidine $(1 \mu \mathrm{Ci} / \mathrm{ml})$ before the determination of acid-insoluble counts. In selected experiments after the holding period, the growth medium was changed to a defined medium constituted by supplementing DME/F12 with BSA $(1 \mathrm{mg} / \mathrm{ml})$, liposomes $(50 \mu \mathrm{g} / \mathrm{ml}$;

1. Abbreviations used in this paper: ANOVA, analysis of variance; $\left[\mathrm{Ca}^{2+}\right]_{\mathrm{i}}$, cytosolic free $\mathrm{Ca}^{2+}$ concentration; DAG, 1,2-diacylglycerol; FBS, fetal bovine serum; FGF, fibroblast growth factor; $\mathrm{IP}_{\mathrm{n}}$, inositol phosphates; $\mathrm{IP}_{1}$, inositol (1)-phosphate; $\mathrm{IP}_{2}$, inositol $(1,4)$-bisphosphate; $\mathrm{IP}_{3}$, inositol $(1,4,5)$-trisphosphate; PA, phosphatidic acid; PC, phosphorylcholine; $\mathrm{PE}$, phosphorylethanolamine; $\mathrm{pH}_{\mathrm{i}}$, intracellular pH; PtdCho, phosphatidylcholine; PtdEth, phosphatidylethanolamine; PtdIns, inositol phospholipids; rIL-1, human recombinant interleukin- $1 \alpha$. 
Boehringer Mannheim Biochemicals, Indianapolis, IN), insulin (10 $\mu \mathrm{g} / \mathrm{ml})$, transferrin $(10 \mu \mathrm{g} / \mathrm{ml})$, and selenium $(5 \mathrm{ng} / \mathrm{ml})$.

Phospholipid analyses. Mesangial cells were either labeled with 1 $\mu \mathrm{Ci} / \mathrm{ml} \mathrm{AA}\left(5,6,8,9,11,12,14,15\left[{ }^{3} \mathrm{H}\right](\mathrm{N})\right.$; New England Nuclear, Boston, MA, $100 \mathrm{Ci} / \mathrm{mmol}$ ) for $2 \mathrm{~h}$ to measure 1,2-diacylglycerol (DAG), $50 \mu \mathrm{Ci} / \mathrm{ml}\left[{ }^{32} \mathrm{P}\right]$ orthophosphate for $3 \mathrm{~h}$ to assess changes in phosphoglycerides, or $2 \mu \mathrm{Ci} / \mathrm{ml}$ [methyl $-{ }^{3} \mathrm{H}$ ]choline $(80 \mathrm{Ci} / \mathrm{mmol}$; New England Nuclear), $2 \mu \mathrm{Ci}\left[1-{ }^{3} \mathrm{H}\right]$ ethan-1-ol-2-amine $(23 \mathrm{Ci} / \mathrm{mmol}$; Amersham Corp., Arlington Heights, IL), or L- $\left[3-{ }^{3} \mathrm{H}\right]$ serine $(37 \mathrm{Ci} /$ mmol, Amersham Corp.) for $24 \mathrm{~h}$ to measure both water-soluble phosphorylbases and the polar phosphoglycerides. Preliminary experiments demonstrated that steady-state incorporation of tracer into both rapidly and more slowly labeled phospholipids had occurred by the end of the labeling period. At the time of the experiment, unless otherwise indicated, radioisotope was removed, the monolayers were gently washed, radiolabel-free, ice-cold Krebs-Henseleit-Hepes $(20 \mathrm{mM})$ buffer was added, and the cells were rewarmed to $37^{\circ} \mathrm{C}$. rIL-1 at the indicated dose in $0.2 \%$ BSA or vehicle was added for, the designated times. The incubations were terminated after various intervals with 1 $\mathrm{ml}$ ice-cold methanol, and the cells scraped and transferred into $1 \mathrm{ml}$ chloroform. A second methanol wash was added and after $30 \mathrm{~min}$ at $4^{\circ} \mathrm{C}$ the methanol and chloroform volumes were adjusted to yield two phases (chloroform/methanol/water, 1:1:0.9, vol/vol/vol). The chloroform lipid extracts were washed twice, dried under $\mathrm{N}_{2}$, and resuspended in $75 \%$ chloroform $/ 25 \%$ methanol. The samples and appropriate standards were spotted on silica gel 60 -plates $(250-\mu \mathrm{m}$ thickness; EM Science, Gibbstown, NJ). Neutral lipids were eluted from the origin with a mobile phase consisting of benzene/diethylether/ammonia (100/80/0.2, vol/vol/vol) (5). DAG was well separated from 1,3DAG, monoacylglycerol, triacylglycerol, phospholipids, and free arachidonate. The neutral lipids were visualized by toluidino-2-naphthalene-sulfonic acid spray and ultraviolet light. The lipids that comigrated with authentic DAG were scraped and radioactivity was determined in a liquid scintillation counter. Phosphatidic acid (PA) was resolved from the other major polar phosphoglycerides by using a one-dimensional, dual phase solvent system. After eluting with chloroform/methanol/4.3 $\mathrm{M} \mathrm{NH}_{4} \mathrm{OH}(34: 26: 8, \mathrm{vol} / \mathrm{vol} / \mathrm{vol})$ until the solvent front was $8 \mathrm{~cm}$ from the origin, the plates were dried. Subsequently, the plates were run in the same direction with hexane/diethylether/acetic acid $(70: 30: 2, \mathrm{vol} / \mathrm{vol} / \mathrm{vol})$ to the top of the plate $(15 \mathrm{~cm})$. PA that comigrated with the authentic standards was scraped and incorporated radioactivity counted. Water-soluble extraction products containing radiolabeled phosphorylbases were spiked with the appropriate unlabeled phosphorylbases, redissolved in $50 \%$ ethanol, and separated by TLC with methanol/0.5\% NaCl/ammonia (100:100:2, vol/vol/vol) (6). Phosphorylcholine (PC) was visualized by iodine, and the phosphorylethanolamine (PE) and phosphorylserine derivatives were identified by spraying with ninhydrin spray. The phosphorylated and unphosphorylated forms of the bases were well separated from each other and comigrated with authentic standards. In these experiments the lipid fraction containing the corresponding radiolabeled polar phosphoglycerides and authentic standards were separated using a mobile phase of chloroform/methanol/acetic acid/ $\mathrm{H}_{2} \mathrm{O}(65: 35: 1: 8, \mathrm{vol} / \mathrm{vol} /$ $\mathrm{vol} / \mathrm{vol})$. Where indicated, extracted lipids were assayed for elemental phosphate (7), and cell protein content was determined by the method of Lowry (8).

Polyphosphoinositide formation and measurement of cytosolic free calcium $\left(\left[\mathrm{Ca}^{2+}\right]_{i}\right)$ and $\mathrm{pH}\left(\mathrm{pH}_{i}\right)$. The measurement of water-soluble inositol phosphates $\left(\mathrm{IP}_{\mathrm{n}}\right)$ was performed as previously described using anion-exchange chromatography (9). Authentic $\left[{ }^{3} \mathrm{H}\right]$ inositol (1)-phosphate $\left(\mathrm{IP}_{1}\right),\left[{ }^{3} \mathrm{H}\right]$ inositol $(1,4)$-bisphosphate $\left(\mathrm{IP}_{2}\right)$, and $\left[{ }^{3} \mathrm{H}\right]$ inositol $(1,4,5)$-trisphosphate $\left(\mathrm{IP}_{3}\right)$ were used to standardize the Dowex resin columns and establish recoveries. $\left[\mathrm{Ca}^{2+}\right]_{\mathrm{i}}$ was measured as previously described (9) using the fluorescent $\left[\mathrm{Ca}^{2+}\right]_{\mathrm{i}}$ probe fura- 2 acetoxymethylester (Molecular Probes, Eugene, OR). Fluorescence was monitored at 339/500 $\mathrm{nm}$ excitation/emission wavelengths. The $\mathrm{Ca}^{2+}$-dependent emission was calibrated at the end of each individual experiment as described, using ionomycin and EGTA/Tris $\mathrm{HCl}, \mathrm{pH} 10.5$ (9). To determine $\mathrm{pH}_{\mathrm{i}}$, monolayers were loaded with $3 \mu \mathrm{M} 2^{\prime}, 7^{\prime}$-bis(carboxylethyl)-5(6)-carboxy-fluorescein-penta-acetoxy methylester (Molecular Probes Inc., Junction City, OR) for $30 \mathrm{~min}$ at $37^{\circ} \mathrm{C}$ followed by a 20-min incubation in $2^{\prime}, 7^{\prime}$-bis(carboxylethyl)-5(6)-carboxy-fluorescein-penta-acetoxy methylester-free medium (10). Fluorescence ratios at $440 / 500 \mathrm{~nm}$ excitation and $540 \mathrm{~nm}$ emission wavelengths were recorded with a dual wavelength Bioinstrumentation Group fluorometer (University of Pennsylvania, Philadelphia, PA) for up to $15 \mathrm{~min}$ after addition of rIL-1 $(10 \mathrm{ng} / \mathrm{ml})$. To calculate $\mathrm{pH}_{\mathrm{i}}$, fluorescence readings were obtained at the end of each experiment after replacement of the medium with modified Krebs-Henseleit-Hepes buffer $\left(\mathrm{Na}^{+}\right.$isosmotically substituted by $\left.\mathrm{K}^{+}\right)$at $\mathrm{pH}$ of $6.5,7.0$, and 7.5 in the presence of the $\mathrm{K}^{+} / \mathrm{H}^{+}$ionophore, nigericin $(3 \mu \mathrm{g} / \mathrm{ml})(10)$. Linearity of the fluorescent emission in the $6.5-7.5 \mathrm{pH}$ range was preliminarily established.

\section{Results}

Table I demonstrates that rIL-1 is a comitogen for the mesangial cell. rIL- 1 in the presence of $0.5 \%$ FBS induced a significant dose-dependent increase in DNA synthesis, measured as $\left[{ }^{3} \mathrm{H}\right]$ thymidine incorporation in quiescent mesangial cells (Table I). DNA synthesis was not initiated in quiescent cells either by rIL- 1 in the absence of serum (98.6 \pm 9 and $90.8 \pm 5.9 \%$ of control for rIL-1, 1.0 and $10 \mathrm{ng} / \mathrm{ml}$, respectively, $n=4)$ or by denatured $\left(100^{\circ} \mathrm{C}\right.$ for $\left.60 \mathrm{~min}\right)$ rIL-1 in the presence of serum $(95 \pm 3.4,101.7 \pm 4.7$, and $102 \pm 3.0 \%$ of control for rIL-1, $0.1,1$, and $10 \mathrm{ng} / \mathrm{ml}$, respectively, $n=2$ ). This data suggests that a comitogen supplied by serum is necessary for IL-1-induced mesangial cell mitogenesis, and confirms studies using partially purified macrophage supernatants as sources of IL-1 (4). To address this issue further, we used a fully defined medium that supports mesangial cell growth. DNA synthesis was stimulated in $\mathrm{G}_{0}$-arrested cells by changing from holding to defined medium. Addition of fibroblast growth factor (FGF) at submitogenic concentrations or rIL-1 did not further enhance DNA synthesis. However, rIL-1 and FGF synergistically increased $\left[{ }^{3} \mathrm{H}\right]$ thymidine incorporation $(184 \pm 6 \%$ of control, $n=3$ ). These studies demonstrate that rIL-1 is a comitogen for the mesangial cell, but the transmembrane signals induced by rIL- 1 alone are not sufficient to cause mesangial cell proliferation.

Table I. Stimulation of DNA Synthesis in Mesangial Cells

\begin{tabular}{|c|c|c|c|}
\hline Medium & $\begin{array}{l}\text { Addition incorporation } \\
\text { (percent of control) }\end{array}$ & {$\left[{ }^{3} \mathrm{H}\right]$ Thymidine } & \\
\hline \multirow[t]{9}{*}{ Holding } & None & 100 & \\
\hline & rIL-1 $(0.01 \mathrm{ng} / \mathrm{ml})$ & $109 \pm 4$ & \\
\hline & $(0.1 \mathrm{ng} / \mathrm{ml})$ & $112 \pm 7$ & \\
\hline & $(0.5 \mathrm{ng} / \mathrm{ml})$ & $135 \pm 6$ & \\
\hline & $(1.0 \mathrm{ng} / \mathrm{ml})$ & $124 \pm 3$ & \\
\hline & $(10 \mathrm{ng} / \mathrm{ml})$ & $123 \pm 5$ & \\
\hline & PA $(50 \mu \mathrm{g} / \mathrm{ml})$ & $130 \pm 4$ & \\
\hline & $\operatorname{PtdCho}(50 \mu \mathrm{g} / \mathrm{ml})$ & $94 \pm 3$ & \\
\hline & TPA $(1 \mathrm{nM})$ & $210 \pm 35$ & \\
\hline \multirow[t]{4}{*}{ Defined } & None & 100 & \\
\hline & rIL-1 (10 ng/ml) & $95 \pm 11$ & \\
\hline & FGF $(10 \mathrm{ng} / \mathrm{ml})$ & $112 \pm 13$ & \\
\hline & rIL-1 + FGF & $184 \pm 6$ & \\
\hline
\end{tabular}

Increasing doses of rIL-1 stimulated a significant increase in $\left[{ }^{3} \mathrm{H}\right]$ thymidine incorporation. $P<0.05 \mathrm{Kruskal}-W$ allis analysis of variance (ANOVA) by ranks. 
We next studied early biochemical events, postulated to initiate proliferation and cellular responses mediated by other cytokines, that could also be generated by IL-1 and that could, in part, contribute to mesangial cell mitogenesis. Studies describing the initial second messengers generated by mitogens have concentrated on the hydrolysis of inositol phospholipids (PtdIns) by a phosphodiesterase, phospholipase C (11). This pathway produces DAG, a cofactor for protein kinase $\mathrm{C}$, and $\mathrm{IP}_{\mathrm{n}}$ including $\mathrm{IP}_{3}$, which mobilizes calcium from nonmitochondrial, intracellular stores. We measured the generation of DAG in control and rIL-1-stimulated mesangial cells to identify an IL-1-activated phospholipase C. Compared with control, rIL-1 induced a time-dependent, statistically significant increase of $\left[{ }^{3} \mathrm{H}\right]$ arachidonate-labeled DAG (Fig. $1 A$ ). Maximal stimulation $(192 \pm 33 \%, n=5)$ occurred at $1 \mathrm{~min}$ and subsequently decreased after $5 \mathrm{~min}$ to $119 \pm 12 \%$ and remained elevated at that level for $60 \mathrm{~min}$. The maximal stimulation of DAG at 1 min occurred with concentrations of rIL-1 between 1 and $10 \mathrm{ng} / \mathrm{ml}$, although concentrations as low as $0.1 \mathrm{ng} / \mathrm{ml}$ had an effect (data not shown). In intact cells, DAG may be rapidly phosphorylated to PA by DAG kinase (12). Therefore, to amplify DAG formation, we next preincubated mesangial cells for 15 min with the DAG kinase inhibitor R59 022 (13). rIL-1 induced a marked and prolonged increase in DAG formation (Fig. $1 B$ ) which now peaked at $5 \mathrm{~min}$ and returned to

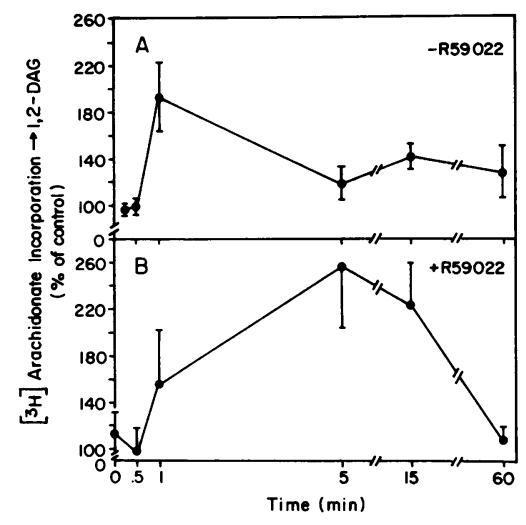

Figure 1. $\left[{ }^{3} \mathrm{H}\right] \mathrm{DAG}$ generation in rIL-1stimulated rat mesangial cells in the absence $(A)$ or presence $(B)$ of the DAG kinase inhibitor R59 $022(10 \mu \mathrm{M})$. Mesangial cells were labeled with $\left[{ }^{3} \mathrm{H}\right] \mathrm{AA}$. In $A$, radioisotope was removed before the addition of rIL-1 (3.6 $\mathrm{ng} / \mathrm{ml}$ ) or vehicle for the designated times. Representative proteins were assayed in parallel

wells for each experiment. Data are expressed as percent of control (mean \pm SEM, $n=5$ ). At 15 s rlL-1-treated mesangial cells incorporated $47.1 \pm 5.5 \mathrm{cpm} / \mu \mathrm{g}$ protein into the DAG area while control cells incorporated $51.4 \pm 4.0 \mathrm{cpm} / \mu \mathrm{g}$ protein $(n=5)$. Data expressed as $\mathrm{cpm} / \mu \mathrm{g}$ protein were statistically analyzed. rIL-1-induced $\left[{ }^{3} \mathrm{H}\right] \mathrm{DAG}$ formation was significantly greater than control $(P<0.05)$ at 1 and 15 min by independent $t$ test after establishing significant differences between groups $(P<0.05)$ by two-way ANOVA. In $B,\left[{ }^{3} \mathrm{H}\right]$ arachidonate was not removed to maintain the labeling of phospholipids at constant specific activity. Vehicle $(0.005 \% \mathrm{HCl})$ or the DAG kinase inhibitor $10 \mu \mathrm{M}$ R59 022 (13; Calbiochem-Behring Corp., La Jolla, CA) was added $15 \mathrm{~min}$ before the addition of rIL-1. At time 0 (rIL-1 or vehicle and methanol added simultaneously) $\left[{ }^{3} \mathrm{H}\right]$ arachidonate incorporation into DAG was $56.5 \pm 7.4$ and $54.8 \pm 9.8 \mathrm{cpm} / \mu \mathrm{g}$ protein for rIL-1 $(10 \mathrm{ng} / \mathrm{ml})$ treated and control cells, respectively. $\left[{ }^{3} \mathrm{H}\right]$ Arachidonate incorporation was stable from 1 to $60 \mathrm{~min}$ in control cells. Data are expressed as percent of control and represent duplicate or triplicate determinations in two separate experiments. Statistical analysis of data as described above expressed as $\mathrm{cpm} / \mu \mathrm{g}$ protein showed a significant increase in IL-1-elicited DAG formation at 5 and $30 \mathrm{~min}(P<0.05)$.

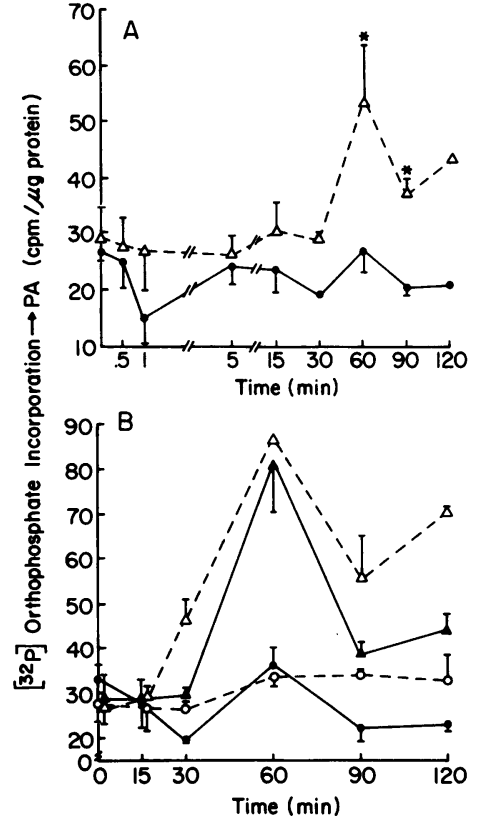

Figure 2. [ $\left.{ }^{32} \mathrm{P}\right] \mathrm{PA}$ formation in rIL-1-treated or control mesangial cells in the absence $(A)$ or presence $(B)$ of the DAG kinase inhibitor R59 022. In $A$, rIL-1 $(10 \mathrm{ng} / \mathrm{ml})$ or $0.2 \%$ BSA was added in the presence of radiolabel for the indicated periods $(\bullet$, control, $\Delta$, rIL-1). The data presented represent the mean \pm SEM of replicate determination in four experiments. ${ }^{*} P<0.05$; treatment group vs. control group by $t$ test after establishing significant differences between groups by ANOVA $(P<0.01)$. In $B$, either R59 $022(10 \mu \mathrm{M})$ or vehicle $(0.005 \% \mathrm{HCl})$ were added $15 \mathrm{~min}$ before the addition of rIL-1 (10

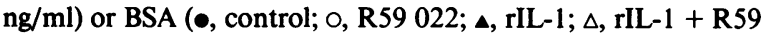
022 ). The data represent the mean \pm SEM of replicate determination of two experiments. Two-way ANOVA established a significant $(P$ $<0.05$ ) difference between rIL-1-treated and control groups.

levels comparable to those measured in the absence of R59 022 by $60 \mathrm{~min}$.

The formation of DAG and PA are often temporally coincident $(12,14)$. As a consequence, we expected an increase in PA to parallel the formation of DAG in rIL-1-stimulated mesangial cells. Rather than a rapid peak, rIL-1 significantly stimulated $\left[{ }^{32} \mathrm{P}\right] \mathrm{PA}$ formation only after rather prolonged incubations of $60 \mathrm{~min}$ (Fig. $2 \mathrm{~A}$ ). As previously reported (15), arginine vasopressin (AVP) stimulated $\left.{ }^{32} \mathrm{P}\right] \mathrm{PA}$ formation which was detectable after $1 \mathrm{~min}$, peaked at $5 \mathrm{~min}(24.2 \pm 3.0$ and $56.9 \pm 4.7 \mathrm{cpm} / \mu \mathrm{g}$ protein, control and AVP-treated cells, respectively) and returned to baseline before the rIL-1-induced increase. Phosphorylation of DAG by DAG kinase may result in the formation of PA (12). The DAG kinase inhibitor R59 022 had no effect on rIL-1-induced increases in [ $\left.{ }^{32} \mathrm{P}\right] \mathrm{PA}$ levels (Fig. 2 B). R59 022 itself enhanced $\left.{ }^{32} \mathrm{P}\right] \mathrm{PA}$ after incubation of 90-120 min, a phenomenon previously reported (13). However, the percent stimulation of [ $\left.{ }^{32} \mathrm{P}\right] \mathrm{PA}$ formation above basal by rIL-1 was equivalent between R59 022-treated and untreated cells at $30,60,90$, and 120 min (data not shown). rIL-1-stimulated PA formation may also result from de novo synthesis. The major phosphoglycerides are derived from PA (14), although the pathways that use cytidine diphosphate-ethanolamine and -choline but not PA can lead to the formation of phosphatidylethanolamine(PtdEth) and phosphatidylcholine (PtdCho) but not phosphatidylglycerol in eukaryotic cells. We therefore measured phosphatidylglycerol in addition to PA in both control and rIL-1-stimulated mesangial cells to indirectly assess changes in lipid mass. rIL-1 had no effect on the amount of label incorporated into phosphatidylglycerol in incubations as long as $120 \mathrm{~min}$ (data not shown). In additional experiments, rIL-1 did not alter total lipid phosphorus/ $\mu \mathrm{g}$ protein in dried chloroform extracts at 1,60 , and $120 \mathrm{~min}$. Total lipid phosphorus was $4.07 \pm 0.98$ and $4.36 \pm 0.27 \mathrm{ng}$ phospho- 
rus/mg protein at $1 \mathrm{~min}$ and $4.04 \pm 0.46$ and $4.27 \pm 0.20$ at 120 min for control and experimental cells, respectively.

The absence of de novo phospholipid synthesis suggests that rIL-1-elicited DAG formation may result from hydrolysis of a phosphoglyceride by phospholipase $\mathrm{C}$, a pathway most commonly linked to PtdIns turnover (11). However, in incubations as long as $90 \mathrm{~min}$, there was no detectable rIL-1-stimulated increase in any of water-soluble $\left[{ }^{3} \mathrm{H}\right] \mathrm{IP}_{\mathrm{n}}\left(\mathrm{IP}_{1}, \mathrm{IP}_{2}, \mathrm{IP}_{3}\right.$, not shown). In contrast, AVP stimulated the rapid formation of $\mathrm{IP}_{3}$ within $5 \mathrm{~s}(3.95 \pm 1.34$ and $12.54 \pm 0.15 \mathrm{cpm} / \mu \mathrm{g}$ protein, control and AVP-stimulated mesangial cells, respectively, $n$ $=2)$, followed by a later peak of $\mathrm{IP}_{2}$ at $30 \mathrm{~s}(4.76 \pm 0.79$ and $10.23 \pm 4.45 \mathrm{cpm} / \mu \mathrm{g}$ protein, control and AVP-stimulated mesangial cells, respectively, $n=2$ ), and an increase of $\mathrm{IP}_{1}$ that persisted at $5 \mathrm{~min}(36.88 \pm 5.44$ and $73.34 \pm 28.6 \mathrm{cpm} / \mu \mathrm{g}$ protein, control and AVP-stimulated mesangial cells, respectively, $n=2$ ). Since $\mathrm{IP}_{3}$ releases calcium from intracellular, nonmitochondrial stores (11), we also measured changes in $\left[\mathrm{Ca}^{2+}\right]_{\mathrm{i}}$ in concomitant experiments. As illustrated in Fig. $3 \mathrm{~A}$, rIL-1 failed to alter $\left[\mathrm{Ca}^{2+}\right]_{i}$, providing further evidence that rIL-1 does not activate a phospholipase $C$ linked to PtdIns (4,5)-bisphosphate, the PtdIns source of $\mathrm{IP}_{3}$. AVP added to the same monolayer subsequently to rIL-1 stimulated a rapid four- to fivefold increase in $\left[\mathrm{Ca}^{2+}\right]_{\mathrm{i}}$ (Fig. $3 \mathrm{~A}$ ) consistent with immediate generation of $\mathrm{IP}_{3}$.

Receptor-mediated activation of a phospholipase $\mathrm{C}$ exclu sively linked to phospholipids other than the PtdIns has been postulated (16). We next investigated, in control and rIL-1-exposed mesangial cells, the formation of water-soluble phosphorylbases that would result by hydrolysis of PtdCho, PtdEth, and phosphatidylserine by phospholipase $C$. As shown in Table II, at 1 min rIL-1 caused a $157.9 \pm 20.0 \%(n=7)$ peak increase in the release of $\left.{ }^{3} \mathrm{H}\right] \mathrm{PE}$. After the initial rapid increase, $\left[{ }^{3} \mathrm{H}\right] \mathrm{PE}$ decreased slightly but remained elevated above control through $60 \mathrm{~min}$, a pattern that paralleled rIL-1-induced charges in DAG concentration. No significant differences in amounts of $\left[{ }^{3} \mathrm{H}\right] \mathrm{PC}$ or $\left[{ }^{3} \mathrm{H}\right]$ phosphorylserine were observed between control and rIL-1-stimulated mesangial cells. Since PtdCho can be synthesized by methylation of PtdEth, mesangial cells labeled with $\left[{ }^{3} \mathrm{H}\right]$ ethanolamine incorporated radiolabel into both PtdEth $(438.3 \pm 38.5 \mathrm{cpm} / \mu \mathrm{g}$ protein) and PtdCho $(64.3 \pm 1.5 \mathrm{cpm} / \mu \mathrm{g}$ protein). If the phospholipase $\mathrm{C}$ activated by IL-1 is specific for PtdEth, the ratio $\left[{ }^{3} \mathrm{H}\right] \mathrm{PE} /$ $\left[{ }^{3} \mathrm{H}\right] \mathrm{PC}$ should increase with time in $\left[{ }^{3} \mathrm{H}\right]$ ethanolamine-labeled cells. In rIL-1-stimulated mesangial cells, the ratio of radioactivity in $\left[{ }^{3} \mathrm{H}\right] \mathrm{PE} /\left[{ }^{3} \mathrm{H}\right] \mathrm{PC}$ increased from $0.825 \pm 0.126$ at time 0 to $1.08 \pm 0.32$ at $1 \mathrm{~min}(n=4)$. Additionally, at $1 \mathrm{~min}\left[{ }^{3} \mathrm{H}\right]$ etha-
Table II. Production of $\left[{ }^{3} H\right] P E,\left[{ }^{3} H\right] P C$, and $\left[{ }^{3} H\right] P S$ in rIL-1-stimulated Mesangial Cells

\begin{tabular}{|c|c|c|c|c|c|c|}
\hline \multirow{2}{*}{$\begin{array}{l}{\left[{ }^{3} \mathrm{H}\right] \text { Phos- }} \\
\text { phorylbase }\end{array}$} & \multirow[b]{2}{*}{$n$} & \multirow[b]{2}{*}{ Agonist } & \multicolumn{4}{|c|}{ Time } \\
\hline & & & 0 & 1 & 5 & 60 \\
\hline & & & \multicolumn{4}{|c|}{$\mathrm{cpm} / \mu \mathrm{g}$ protein } \\
\hline PE & 7 & rIL-1 & $254.1 \pm 41.6$ & $410.6 \pm 85.2^{*}$ & $381.5 \pm 62.1^{*}$ & $354.9 \pm 57.9^{*}$ \\
\hline PC & 10 & rIL-1 & $161.1 \pm 37.5$ & $143.6 \pm 30.5$ & $128.0 \pm 31.1$ & $141.6 \pm 31.2$ \\
\hline PS & 6 & rIL-1 & $0.95 \pm 0.2$ & $0.88 \pm 0.26$ & $0.72 \pm 0.16$ & $1.10 \pm 0.37$ \\
\hline
\end{tabular}

Results represent mean \pm SEM of duplicate determination from indicated number of experiments. rIL-1 or vehicle and methanol were added simultaneously to obtain time zero values. $\mathrm{Cpm} / \mu \mathrm{g}$ protein values for production of $\left[{ }^{3} \mathrm{H}\right]$ phosphorylbases in vehicle-treated mesangial cells did not change over time and control time zero values did not differ significantly from rIL-1-treated time zero values. ${ }^{*} P<0.05$ IL-1-stimulated vs. vehicle-stimulated mesangial cells by independent $t$ test comparison after establishing a significant difference between experimental conditions by two-way ANOVA $(P<0.05)$.

nolamine incorporated into PtdEth was decreased in rIL-1stimulated mesangial cells $(389.4 \pm 41.8, n=3)$ compared with mesangial cells exposed to vehicle $(483.2 \pm 78.2 \mathrm{cpm} / \mu \mathrm{g}$ protein, $n=3$ ). In contrast, $\left[{ }^{3} \mathrm{H}\right]$ choline incorporated into PtdCho was similar in both IL-1-stimulated and control cells $(1,078.3 \pm 160.4$ vs. $983.63 \pm 198.1 \mathrm{cpm} / \mu \mathrm{g}$ protein, experimental and control cells, respectively, $n=3$ ).

Changes in $\mathrm{pH}_{\mathrm{i}}$ commonly occur after stimulation by growth factors and reflect several different $\mathrm{H}^{+}$transporting mechanisms. Many studies have demonstrated that agoniststimulated changes in $\mathrm{pH}_{\mathrm{i}}$ result from activation of an amiloride-sensitive $\mathrm{Na}^{+} / \mathrm{H}^{+}$antiporter by protein kinase $C$, although $\mathrm{Na}^{+} / \mathrm{H}^{+}$exchange can also be initiated by kinase $\mathrm{C}$-independent mechanisms (17). Since rIL-1-stimulated DAG formation could activate protein kinase $\mathrm{C}$, we measured $\mathrm{pH}_{\mathrm{i}}$ in control and rIL-1-stimulated mesangial cells. In contrast to other mitogens, rIL-1 did not induce an acute change in $[\mathrm{pH}]_{\mathrm{i}}$ in mesangial cells (Fig. $3 \mathrm{~B}$ ). AVP, however, induced a rapid, transient acidification followed by sustained cytoplasmic alkalinization (Fig. $3 \mathrm{~B}$ ).

Second messengers should mimic the cytokine-stimulated cellular response. Both 12-0-tetradecanoyl-phorbol-13-acetate, a homologue for endogenous DAG, and egg yolk lecithin PA, in the presence of $0.5 \%$ serum, stimulated mesangial cell DNA synthesis as measured by $\left[{ }^{3} \mathrm{H}\right]$ thymidine incorporation (Table I). In contrast, PtdCho had no effect on mesangial cell DNA synthesis. Similar to the conditions necessary for rIL-1-stimu-

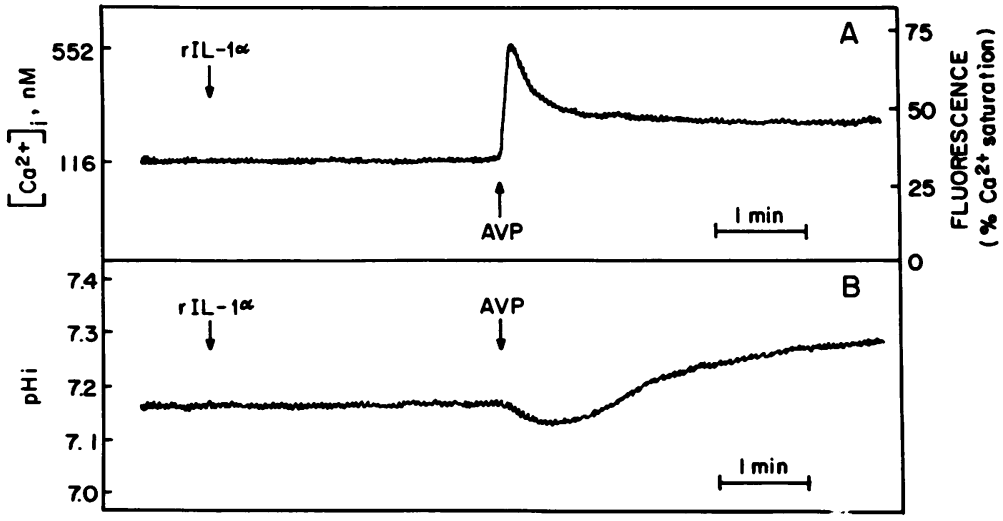

Figure 3. Continuous monitoring of $\left[\mathrm{Ca}^{2+}\right]_{\mathrm{i}}(A)$ and $\mathrm{pH}_{\mathrm{i}}$ $(B)$ in confluent monolayers of rat mesangial cells exposed to rIL-1. Tracings are representative of 17 experiments in which cells were exposed to rIL-1, 3.6-360 $\mathrm{ng} / \mathrm{ml}(A)$ or 21 experiments in which cells were exposed to rIL-1, $10 \mathrm{ng} / \mathrm{ml}(B)$. AVP $(100 \mathrm{nM})$ was used as an internal positive control in both series of experiments. 
lated mesangial cell proliferation, neither compound increased $\left[{ }^{3} \mathrm{H}\right]$ thymidine incorporation in the absence of serum.

\section{Discussion}

Little information describing the transmembrane signals generated by IL-1 has previously been published. Although both IL- $1 \alpha$ and IL- $1 \beta$ stimulated amiloride-sensitive $\mathrm{Na}^{+} / \mathrm{H}^{+}$exchange after $1 \mathrm{~h}$ in the transformed pre-B lymphocyte cell line $70 \mathrm{Z} / 3$, intracellular alkalinization or increased cytosolic $\mathrm{Na}^{+}$ was not necessary for Il-1-mediated 70Z/3 differentiation (18). We did not monitor $\mathrm{pH}_{\mathrm{i}}$ in prolonged incubations but were clearly unable to demonstrate the acute changes in $\mathrm{pH}_{\mathrm{i}}$ that have been observed in response to other cytokines and hormones (17). Other workers have also failed to show any effects of IL-1 on $\left[\mathrm{Ca}^{2+}\right]_{i}$ concentration or PtdIns turnover $(19,20)$. These data suggest that other transmembrane signals mediate at least some of IL-1's biological effects.

We have demonstrated a rapid rIL-1-stimulated increase in DAG. Although we used only IL- $1 \alpha$ in these studies, both IL- $1 \alpha$ and IL- $1 \beta$ share a common receptor despite being only distantly homologous, and thus far have been shown to have only quantitatively but not qualitatively different biologic actions. DAG is a phospholipid-derived signal that can activate protein kinase $C$, and Levine and Xiao have suggested that IL-1 directly or indirectly stimulates kinase $\mathrm{C}$ activity in both liver and smooth muscle cells (21). Other studies that use lymphocytes as targets of IL- 1 suggest IL-1 elicits cellular responses by a mechanism that involves neither an increase in $\left[\mathrm{Ca}^{2+}\right]_{\mathrm{i}}$ nor stimulation of protein kinase $\mathrm{C}$ activity $(19,20)$. These findings suggest that IL-1-stimulated DAG may induce signals independent of protein kinase $\mathrm{C}$ activation. Recent evidence is consistent with this hypothesis. FGF, like rIL-1, stimulates DAG formation independent of polyphosphoinositide turnover, but does not activate protein kinase C (22). Priming and primed stimulation of neutrophils by 1-oleoyl-2acetylglycerol occurs by mechanisms distinct from kinase C translocation (23). Desensitization or inhibition of protein kinase $C$ only partially reduced the amplification of bradykininstimulated $\mathrm{PGE}_{2}$ synthesis by DAG analogues (24). The fatty acid composition of agonist-stimulated DAG formation may be a critical determinant of its ability to activate protein kinase C (25). Targets of DAG other than kinase $C$ have not been identified but Nishizuka has suggested that DAG may be a source of arachidonate. Eicosanoids have been implicated previously as components of IL-1-stimulated transmembrane signal pathways (26).

DAG formation may be the result of two separate pathways. Phosphohydrolase activity generates DAG from PA produced by de novo synthesis from glycerol, a pathway of importance in insulin transmembrane signaling (14). Both the lack of a coincident rise in rIL-1-stimulated DAG and PA formation in our studies and the evidence suggesting that lipid mass is constant argue against, but do not disprove, this mechanism. DAG is also produced by receptor-mediated phospholipase $\mathrm{C}$ activity (11). Our findings suggest rIL-1-generated DAG is the result of a phospholipase $C$ that is distinct from a PtdIns-specific phosphodiesterase and that predominantly hydrolyzes PtdEth. rIL-1-stimulated DAG peaked at $1 \mathrm{~min}$, coincident with an increase in the phospholipase $\mathrm{C}$ hydrolysis product $\left[{ }^{3} \mathrm{H}\right] \mathrm{PE}$ and a decrease in $\left[{ }^{3} \mathrm{H}\right] \mathrm{PtdE}$ th. However, these results need to be confirmed by mass measurements since a recent study has demonstrated discrepancies in lipid mea- surements obtained using label and those obtained using mass (27).

Others have suggested that phospholipids other than PtdIns are substrates for phospholipase C. FGF increased DAG independent to PtdIns hydrolysis, but the phospholipid source of the DAG was not determined (22). A neutral active phospholipase $\mathrm{C}$ specific for PtdCho and PtdEth has been isolated from myocardium (28). Bestermen et al. reported that phorbol dibutyrate stimulated DAG and PC accumulation in Swiss $3 \mathrm{~T} 3$ cells (16) and hypothesized that protein kinase C, activated directly by phorbol esters or indirectly by DAG produced by agonist-induced PtdIns turnover, stimulates a PtdCho-specific phospholipase C. Subsequent work has suggested that GTP-binding proteins rather than kinase $\mathrm{C}$ directly mediate activation of a PtdCho-linked phospholipase C (29). Consistent with this observation, the Ha-ras protein, which has GTP-binding, protein-like activities, stimulates phospholipase C-mediated hydrolysis of PtdEth as well as PtdCho but not PtdIns (6). However, IL-1 is the only example of peptide hormone- or cytokine-mediated activation of phospholipase $\mathrm{C}$ in the absence of concomitant PtdIns hydrolysis.

Since others have suggested that phosphorylation of DAG by DAG kinase is a major pathway of DAG metabolism, we were surprised to find that peak rIL-1-stimulated DAG production occurred at $1 \mathrm{~min}$ in the absence of measurable PA formation. However, PA formation did occur after $60 \mathrm{~min}$ in the absence of significant DAG formation. Although the DAG kinase inhibitor R59 022 potentiated the effect of rIL-1 on DAG generation, our results suggest that this pathway is quantitatively unimportant in PA formation in rIL-1-treated mesangial cells. It might be argued that at least some PA should be produced concurrent with peak IL-1-stimulated DAG formation since the DAG kinase inhibitor potentiates the response. We may be unable to detect by radiolabeling small changes in PA production at 1 min since changes in lipid mass are underestimated when assessed by radiolabel incorporation (27). In addition, formation of PA by phosphorylation of DAG may depend on the fatty acids in the 1,2-sn configuration of the DAG. Platelet-derived growth factor-stimulated DAG kinase exhibits substrate specificity that preferentially phosphorylates 18:0/20:4 DAG over didecanoylglycerol (30). Other studies have suggested that phosphorylation of DAG may not contribute to the bulk of agonist-induced PA formation in all cells, including platelets, mesangial cells, and Leydig cells. In hepatocytes, AVP-stimulated PA production did not involve phosphorylation of DAG but resulted from activation of phospholipase $D$, an enzyme that hydrolyzes phospholipids to PA (31). rIL-1-elicited increases in PA production in mesangial cells occur by mechanisms, at least in part, independent of the phosphorylation of DAG or de novo synthesis and may result from phospholipase D activity. More work is needed to definitively delineate the relative contributions of DAG phosphorylation, activation of phospholipase $\mathrm{D}$, and de novo synthesis.

IL-1 is a comitogen for mesangial and other cells, and an additional signal(s) must be supplied by another mitogen to initiate proliferation. In addition, the phospholipid-derived messengers stimulated by IL-1 in the presence of comitogen may qualitatively or quantitatively differ from those presented in our study. However, the biological relevance of the biochemical changes elicited by rIL-1 is suggested by experiments demonstrating that both 12-0-tetradecanoyl-phorbol-13-acetate, a DAG substitute, and PA mimic rIL-1-induced mesangial cell proliferation in the presence but not absence of $0.5 \%$ FBS. These studies do not prove that either signal is necessary 
or sufficient for eliciting IL-1-mediated cellular response. The physiologic significance of enhanced PE is unknown. However, the notion that PA functions as a second messenger is not new (32). Exogenous PA stimulates proliferation, inhibits adenylate cyclase, activates phosphorylase, and increases $\left[\mathrm{Ca}^{2+}\right]_{i}$. Whether endogenous PA affects metabolic processes in the same way has not been established. Our studies demonstrate that rIL-1 independently stimulates both hydrolysis of PtdEth and increases PA production in the mesangial cells and suggest that those changes, in part, may be transmembrane signals by which IL-1 elicits cellular responses.

\section{Acknowledgments}

We thank J. Orehek, R. Ondash, and N. Njoku for technical assistance, and Deborah Tierk for preparing the manuscript. We also wish to thank Dr. Peter Lomedico, Hoffman-La Roche, Nutley, NJ, for the generous gift of rIL-1.

This work was supported by DK-38558, HL-22563, BRSG-507 RR-05410-25, the Mather Charitable Trust, the Kidney Foundation of Ohio and the American Heart Association, Northeast Ohio Affiliate. Dr. Sedor is a recipient of a Clinical Investigator Award.

Note added in proof. Rosoff et al. (1988. Cell. 54:73-81.) have recently demonstrated in Jurkat cells that IL-1 stimulates rapid DAG and PC from PtdCho in the absence of AdIns turnover.

\section{References}

1. Dinarello, C. R. 1985. An update on human interleukin-1: from molecular biology to clinical relevance. J. Clin. Immunol. 5:287-297.

2. Schlondorff, D. 1987. The glomerular mesangial cell: an expanding role for a specialized pericyte. FASEB (Fed. Am. Soc. Exp. Biol.) J. 1:272-281.

3. Werber, H. I., S. N. Emancipator, M. L. Tykocinski, and J. R. Sedor. 1987. The interleukin-1 gene is expressed by rat glomerular mesangial cells and is augmented in immune complex glomerulonephritis. Immunology. 138:3207-3212.

4. Lovett, D. H., and A. Larsen. 1988. Cell cycle-dependent interleukin-1 gene expression by cultured glomerular mesangial cells. $J$. Clin. Invest. 82:115-122.

5. Griendling, K. K., S. E. Rittenhouse, T. A. Brock, L. S. Eckstein, M. A. Gimbrone, and W. A. Alexander. 1986. Sustained diacylglycerol formation from inosital phospholipids in angiotensin II-stimulated vascular smooth muscle cells. J. Biol. Chem. 261:5901-5906.

6. Lacal, J. D., J. Museat, and S. A. Aaronson. 1987. Novel source of 1,2-diacylglycerol elevated in cells transformed by Ha-ras oncogene. Nature (Lond.). 330:269-272.

7. Eng, L. F., and E. P. Noble. 1968. The maturation of rat brain myelin. Lipids. 3:157-162.

8. Lowry, O. H., N. J. Rosebrough, A. L. Farr, and R. J. Randall. 1951. Protein measurement with the Folin phenol reagent. J. Biol. Chem. 193:265-275.

9. Mené, P., H. E. Abboud, G. R. Dubyak, A. Scarpa, and M. J. Dunn. 1987. Effects of PDGF on inositol phosphates, $\mathrm{Ca}^{2+}$, and contraction of mesangial cells. Am. J. Physiol. 253 (Renal and Fluid Electrolyte Physiol. 22):F458-F463.

10. Grinstein, S., J. Cohen, and J. Rothstein. 1984. Cytoplasmic $\mathrm{pH}$ regulation in thymic lymphocytes by an amiloride-sensitive $\mathrm{Na}^{+} / \mathrm{H}^{+}$antipart. J. Gen. Physiol. 83:341-369.

11. Rozengurt, E. 1986. Early signals in the mitogenic response. Science (Wash. DC). 234:161-166.

12. May, W. S., E. G. Lapetina, and P. Cuatrecasas. 1986. Intracellular activation of protein kinase $C$ and regulation of the surface transferrin receptor by diacylglycerol is a spontaneously reversible process that is associated with rapid formation of phosphatidic acid. Proc. Natl. Acad. Sci. USA. 83:1281-1284.

13. Chaffoy de Courcelles, D., R. Roevens, and H. van Belle. 1985. R59022, a diacylglycerol kinase inhibitor: its effect on diacylglycerol and thrombin-induced $\mathrm{C}$ kinase activation in the intact platelet. $J$. Biol. Chem. 260:15762-15770.
14. Farese, R. V., T. Suman-Konda, J. S. Davis, M. L. Standaert, J. Pollet, and D. R. Cooper. 1986. Insulin rapidly increases diacylglycerol by activating de novo phosphatidic acid synthesis. Science (Wash. DC). 236:586-589.

15. Troyer, D. A., J. I. Kreisberg, D. W. Schwartz, and M. A. Venkatachalam. 1985. Effects of vasopressin on phosphoinositides and prostaglandin production in cultured mesangial cells. Am. J. Physiol. 249 (Renal Fluid Electrolyte Physiol. 18):F139-F147.

16. Besterman, J. M., V. Duronio, and P. Cuatrecasas. 1986. Rapid formation of diacylglycerol from phosphatidylcholine: a pathway for generation of a second messenger. Proc. Natl. Acad. Sci. USA. 83:6785-6789.

17. Huang, C.-L., M. G. Cogan, E. J. Cragoe, and H. E. Ives. 1987. Thrombin activation of the $\mathrm{Na}^{+} / \mathrm{H}^{+}$exchanger in vascular smooth muscle cells. J. Biol. Chem. 262:14134-14140.

18. Calalb, M. B., T. H. Stanton, L. Smith, E. J. Cragoe, and K. Bomsztyk. 1987. Recombinant human interleukin-1-stimulated $\mathrm{Na}^{+} / \mathrm{H}^{+}$exchange is not required for differentiation in pre-B lymphocyte cell line, 70Z/3. J. Biol. Chem. 262:3680-3684.

19. Mukaidu, N., T. Kasahara, H. Yagisawa, K. Shiori-Nakaro, and M. T. Kuwas. 1987. Signal requirement for interleukin-1-dependent interleukin 2 production by a human leukemia-derived HSB-2 subclone. J. Immunol. 139:3321-3329.

20. Abraham, R. T., S. N. Ho, T. J. Barna, and D. J. McKean. 1987. Transmembrane signaling during interleukin 1-dependent $T$ cell activation: interactions of signal 1- and signal 2-type mediators with the phosphoinositide-dependent signal transduction mechanism. $J$. Biol. Chem. 262:2719-2728.

21. Levine, L., and D.-M. Xiao. 1985. The stimulation of arachidonic acid metabolism by recombinant murine interleukin 1 and tumor promoters or 1-oleoyl-2-acetyl-glycerol are synergistic. J. Immunol. 135:3430-3433.

22. Magnaldo, I., G. L'Allemain, J. C. Chambard, M. Moenner, D. Barritault, and J. Pouyssegur. 1986. The mitogenic signaling pathway of fibroblast growth factor is not mediated through polyphosphoinositide hydrolysis and protein kinase $\mathrm{C}$ activation in hamster fibroblasts. J. Biol. Chem. 261:16916-16922.

23. Bass, D. A., C. Gerard, P. Olbrantz, J. Wilson, C. E. McCall, and L. C. McPhail. 1987. Priming of the respiratory burst of neutrophils by diacylglycerol independence from activation or translocation of protein kinase C. J. Biol. Chem. 262:6643-6673.

24. Burch, R. M., A. L. Ma, and J. Axelrod. 1986. Phorbol esters and diacylglycerols amplify bradykinin-stimulated prostaglandin synthesis in Swiss 3T3 fibroblasts: possible independence from protein kinase C. J. Biol. Chem. 263:4764-4767.

25. Nishizuka, Y. 1986. Studies and perspectives of protein kinase C. Science (Wash. DC). 233:305-312.

26. Dinarello, C. A., S. O. Marnoy, and L. J. Rosenwasser. 1983. Role of arachidonate metabolism in the immunoregulatory function of human leukocytic pyrogen/lymphocyte-activating factor/interleukin-I. J. Immunol. 130:890-895.

27. Chilton, F. H., and T. R. Connell. 1988. 1-Ether-linked phosphoglycerides: major endogenous sources of arachidonate in the human neutrophil. J. Biol. Chem. 263:5260-5265.

28. Wolf, R. A., and R. W. Gross. 1985. Identification of neutral active phospholipase $C$ which hydrolyses choline glycerophospholipids and plasmalogen selective phospholipase $\mathrm{A}_{2}$ in canine myocardium. $J$. Biol. Chem. 260:7295-7303.

29. Irving, H. R., and J. H. Exton. 1987. Phosphatidylcholine breakdown in rat liver plasma membranes: roles of guanine nucleotides and $\mathrm{P}_{2}$-purinergic agonists. J. Biol. Chem. 262:3440-3443.

30. MacDonald, M. L., K. F. Mack, C. Nist-Richardson, and J. A. Glomset. 1988. Regulation of diacylglycerol kinase reaction in Swiss 3T3 cells. J. Biol. Chem. 263:1575-1583.

31. Bocckino, S. B., P. F. Blackmore, P. B. Wilson, and J. H. Exton. 1987. Phosphatidate accumulation in hormone-treated hepatocytes via a phospholipase D mechanism. J. Biol. Chem. 262:15309-15315.

32. Moolenar, W. H., W. Kruiger, B. C. Tilly, I. Verlaan, A. J. Bierman, and S. W. de Laat. 1986. Growth factor-like action of phosphatidic acid. Nature (Lond.). 323:171-173. 